\title{
Rhodoglobus vestalii gen. nov., sp. nov., a novel psychrophilic organism isolated from an Antarctic Dry Valley lake
}

\author{
Peter P. Sheridan, ${ }^{1}$ Jennifer Loveland-Curtze, ${ }^{2}$ Vanya I. Miteva ${ }^{2}$ \\ and Jean E. Brenchley² \\ ${ }^{1}$ Department of Biological Sciences, PO Box 8007, Idaho State University, Pocatello, \\ ID 83209, USA
${ }^{2}$ Department of Biochemistry and Molecular Biology, Pennsylvania State University, University Park, PA 16802, USA

Vanya I Miteva

vim1@psu.edu

\begin{abstract}
A novel, psychrophilic, Gram-positive bacterium (designated strain LV3 ${ }^{\top}$ ) from a lake near the McMurdo Ice Shelf, Antarctica, has been isolated and characterized. This organism formed red-pigmented colonies, had an optimal growth temperature of $18^{\circ} \mathrm{C}$ and grew on a variety of media between -2 and $21^{\circ} \mathrm{C}$. Scanning electron micrographs of strain LV $3^{\top}$ that showed small rods with unusual bulbous protuberances during all phases of growth were of particular interest. The $\mathrm{G}+\mathrm{C}$ content of the genomic DNA was approximately $62 \mathrm{~mol} \%$. The cell walls

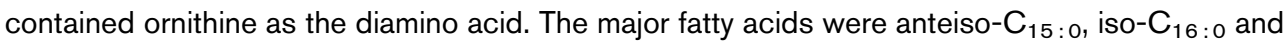
anteiso- $\mathrm{C}_{17: 0}$. Cells grown at $-2{ }^{\circ} \mathrm{C}$ contained significant amounts of anteiso- $\mathrm{C}_{15: 1}$. The major menaquinones found in strain LV3 ${ }^{\top}$ were MK-11 and MK-12. Phylogenetic analysis of the $16 \mathrm{~S}$ rRNA gene sequence indicated that strain $\mathrm{LV}^{\top}{ }^{\top}$ was a member of the family Microbacteriaceae and related to, but distinct from, organisms belonging to the genera Agreia, Leifsonia and Subtercola. In addition, alignments of $16 \mathrm{~S}$ rRNA sequences showed that the sequence of strain LV3 ${ }^{\top}$ contained a $13 \mathrm{bp}$ insertion that was found in only a few related sequences. Based on the low growth temperature, unusual cell shape, distinct 16S rRNA gene sequence and structure and cell-wall amino acid and menaquinone compositions, Rhodoglobus vestalii gen. nov., sp. nov. is

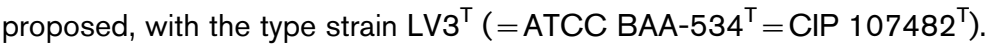

\section{INTRODUCTION}

Our research focuses on the isolation of psychrophiles, i.e. organisms that grow at $5{ }^{\circ} \mathrm{C}$ and have growth optima below $37^{\circ} \mathrm{C}$ (Neidhardt et al., 1990), and the characterization of their cold-active enzymes. We have isolated numerous psychrophilic micro-organisms and characterized several cold-active $\beta$-galactosidases (Coombs \& Brenchley, 1999; de Prada et al., 1996; Gutshall et al., 1995, 1997; Loveland et al., 1994; Loveland-Curtze et al., 1999; Sheridan \& Brenchley, 2000). Many of these strains were members of the high$\mathrm{G}+\mathrm{C}$ actinomycete-coryneform diverse group of bacteria (Stackebrandt \& Woese, 1981). A recent psychrophilic isolate from a lake in the Dry Valley region of Antarctica, designated strain $\mathrm{LV}^{\mathrm{T}}$, had unusual features. Scanning electron micrographs that showed cells with unusual, bulbous protrusions present during all stages of growth were of particular interest. Furthermore, unlike previous

Abbreviation: DAB, diaminobutyric acid.

The GenBank/EMBL/DDBJ accession number for the 16S rRNA gene sequence of strain $L V 3^{\top}$ is AJ459101. isolates, these cells did not have traits typical of members of the genus Arthrobacter, such as a rod-coccus morphological cycle and lysine as the characteristic diamino acid in the peptidoglycan (Loveland-Curtze et al., 1999).

Analyses of the $16 \mathrm{~S}$ rRNA gene sequence from strain $\mathrm{LV}^{\mathrm{T}}$ showed that it was related to, but distinct from, genera such as Agreia, Leifsonia, Subtercola, Agrococcus and Agromyces in the family Microbacteriaceae. This group was recently revised with the addition of novel genera, because analysis of $16 \mathrm{~S}$ rRNA gene sequences had demonstrated that many of the classical groupings were not monophyletic. The genus Leifsonia was proposed in an attempt to create order within this sub-branch of the actinomycete-coryneform bacterial phylogenetic tree (Evtushenko et al., 2000). For example, the organisms formerly known as Clavibacter xyli subsp. cynodontis and subsp. xyli were reclassified as Leifsonia xyli subsp. cynodontis and Leifsonia xyli subsp. xyli, respectively. At the time of writing, there are five species with validly published names in the genus Leifsonia, which form a distinct phylogenetic branch close to the Agromyces cluster. 
We describe here the unusual morphological, chemotaxonomic and phylogenetic characteristics of the psychrophilic strain $\mathrm{LV} 3^{\mathrm{T}}$. Based on unique features and distinct phylogenetic placement, Rhodoglobus vestalii gen. nov., sp. nov. is proposed for strain $\mathrm{LV}^{\mathrm{T}}$.

\section{METHODS}

Sampling and isolation. A cyanobacterial mat sample was collected in January 1993 from a meromictic pond (informally called 'Lake Vestal' in honour of the late J. Robie Vestal) located south of the Miers and Adams glaciers near Bratina Island on the McMurdo Ice Shelf, Antarctica. The sample was frozen at $-80^{\circ} \mathrm{C}$ until approximately $2 \mathrm{~g}$ sample was inoculated into $5 \mathrm{ml}$ instant ocean broth (Loveland-Curtze et al., 1999) and incubated at $10^{\circ} \mathrm{C}$ until the culture became turbid. Organisms were isolated on instant ocean agar by using streak-plating techniques (Loveland-Curtze et al., 1999) and colonies were passed at least three times to ensure purity. Isolates were streaked onto instant ocean agar with $100 \mathrm{mg} \mathrm{X}-\mathrm{Gal}$ $1^{-1}$, to determine those that produced $\beta$-galactosidase. A redpigmented colony designated strain $\mathrm{LV}^{\mathrm{T}}$ that hydrolysed X-Gal was chosen for further study.

Physiological and biochemical characteristics. The ability of the strain to grow at different temperatures and on various media was tested by inoculating cells from a turbid culture grown in R2 broth (Difco) onto plates of R2 agar, Luria-Bertani agar, trypticase soy agar without added carbohydrate, nutrient agar, marine agar and instant ocean agar. The cultures were incubated aerobically at $-2,10,18,25$ and $37^{\circ} \mathrm{C}$. Growth rates were determined by inoculating cells from a turbid culture grown in trypticase soy broth without added carbohydrate (TSB) into fresh TSB to a Klett reading of 10-15, and by incubating aerobically at $-2,5,10,18,21,22$ and $23{ }^{\circ} \mathrm{C}$. API CORYNE test strips (bioMérieux) were used for general characterization of enzymic and fermentation activities and gelatin hydrolysis. The strips were incubated at $18{ }^{\circ} \mathrm{C}$ and the results were recorded after 24 and $48 \mathrm{~h}$.

Electron microscopy. Cells were grown in TSB at 10 or $18{ }^{\circ} \mathrm{C}$ for scanning electron microscopy (SEM). They were washed in $0 \cdot 1 \mathrm{M}$ sodium cacodylate buffer $(\mathrm{pH} 7 \cdot 4)$, filtered onto a $0.2 \mu \mathrm{m}$ pore polycarbonate filter and fixed in $2.5 \%$ glutaraldehyde in $0.1 \mathrm{M}$ sodium cacodylate buffer for $4 \mathrm{~h}$ at $4{ }^{\circ} \mathrm{C}$. After washing, the filters and cells were post-fixed with $1 \% \mathrm{OsO}_{4}$ in $0 \cdot 1 \mathrm{M}$ sodium cacodylate buffer $(\mathrm{pH} 7 \cdot 4)$ and dried in a BAL-TEC model CPD 030 critical point dryer. The preparations were mounted onto aluminium holders, sputter-coated with $10 \mathrm{~nm} \mathrm{Au/Pd}$ and observed by SEM (JEOL model 5400) at $30 \mathrm{kV}$.

For transmission electron microscopy (TEM), cells were pelleted and resuspended in 1-2\% glutaraldehyde in $0.1 \mathrm{M}$ sodium cacodylate buffer $(\mathrm{pH} 7 \cdot 4)$ overnight at $4{ }^{\circ} \mathrm{C}$. After a secondary fixation with $1 \%$ $\mathrm{OsO}_{4}$ in $0 \cdot 1 \mathrm{M}$ sodium cacodylate buffer $(\mathrm{pH} 7 \cdot 4)$, the cells were dehydrated through an alcohol gradient series, infiltrated with an acetone-Spurrs mixture and polymerized in Spurrs resin. Ultrathin sections were taken, stained with $2 \%$ uranyl acetate in ethanol and lead citrate and observed by TEM (JEOL model 1200 EXII) at $80 \mathrm{kV}$. Both the SEM and TEM pictures were taken at the Penn State Electron Microscope Facility.

165 rRNA gene amplification and phylogenetic analyses. Genomic DNA was extracted from strain $\mathrm{LV}^{\mathrm{T}}$ using a modification of standard methods (Giovannoni et al., 1990). The 16S rRNA gene was amplified from chromosomal DNA by PCR using Ready-To-Go beads (Amersham Biosciences) and the universal primers $8 \mathrm{~F}$ and 1492R (Pace et al., 1986; Weisburg et al., 1991). Both strands of the product were sequenced at the Penn State Nucleic Acid Facility on an $\mathrm{ABI} 370$ sequencer. The $16 \mathrm{~S}$ rRNA gene sequence was aligned with those from the Ribosomal Database Project (RDP) (Maidak et al., 2000) and those obtained from a BLAST search of GenBank (http://www.ncbi.nlm.nih.gov), using the CLUSTAL W program found in the BioEdit platform (version 5.0.6). The alignment was based on 1642 nucleotide positions and was used in maximum-parsimony, maximum-likelihood and distance analyses utilizing the PAUP package (version 4.0b10; Swofford, 2002). The maximum-parsimony method utilized a heuristic search, and both the maximum-likelihood (with a transition-transversion ratio of 2) and distance methods were performed using the neighbour-joining algorithm. The initial distance analysis was performed using the neighbour-joining algorithm and an uncorrected ' $\mathrm{p}$ ' distance in the PAUP program. To determine the effects of using various analysis methods on these results, we compared our results with distance trees generated using the Jukes-Cantor, F81, F84, Kimura two-parameter, Kimura threeparameter, Tamura-Nei, Tajima-Nei and HKY 85 models with equal rates for variable sites. Unequal rates for variable sites were also examined for all eight models using $\Gamma$-parameters with shapes of $0 \cdot 5,1 \cdot 0,2 \cdot 0,3 \cdot 0,4 \cdot 0$ and $5 \cdot 0$. Trees generated by all three methods were essentially congruent. A distance matrix was generated from the same alignment by the PAUP program, using the Jukes-Cantor, F81, F84, Kimura two-parameter, Kimura three-parameter, TamuraNei, Tajima-Nei and HKY85 models with equal rates for variable sites. The matrices were quite similar. Ten thousand bootstrap replicates were performed for the distance method, using the Jukes-Cantor model with equal rates for variable sites.

Cell-wall analysis. Cell-wall preparations were hydrolysed and the diamino acids were separated by using a TLC method (Bousfield et al., 1985). Quantitative amino acid analyses were done on cell walls of strain $\mathrm{LV}^{\mathrm{T}}$, prepared according to the short procedure of Schleifer \& Kandler (1972), at the University of Michigan Carbohydrate and Structure Facility. For GC-MS analysis, the cell walls were hydrolysed in $6 \mathrm{M} \mathrm{HCl}$ at $110^{\circ} \mathrm{C}$ and the hydrolysates were dried for $12 \mathrm{~h}$ on a Speed Vac Concentrator (Savant Instruments). After derivatization with $N$-methyl- $N$-(tert-butyldimethylsilyl) trifluoroacetamide (MTBSTFA; Regis Technologies), the preparations were heated for $1 \mathrm{~h}$ at $60^{\circ} \mathrm{C}$. GC-MS cell-wall analysis was carried out at the Penn State Intercollegiate Center for Mass Spectrometry, with a Hewlett Packard model 5972 mass spectrometer.

Fatty acid and lipoquinone analyses. Fatty acid determinations were done on cells of strain $\mathrm{LV} 3^{\mathrm{T}}$ grown in Luria-Bertani (LB) broth at $-2{ }^{\circ} \mathrm{C}$ and in TSB at $18^{\circ} \mathrm{C}$. The cells were centrifuged and the pellets frozen at $-20^{\circ} \mathrm{C}$ and sent to Microbial ID for fatty acid methyl ester analysis. Respiratory lipoquinone analyses were carried out by B. J. Tindall, Deutsche Sammlung von Mikroorganismen und Zellkulturen (DSMZ), Braunschweig, Germany, on freeze-dried cells cultivated in TSB at $18^{\circ} \mathrm{C}$.

DNA base composition. The $\mathrm{G}+\mathrm{C}$ content (mol\%) was calculated for purified DNA extracted from cells of strain $\mathrm{LV}^{\mathrm{T}}$ by determining the melting temperature as described by Mandel \& Marmur (1968). The melting temperature of purified chromosomal DNA extracted from Escherichia coli ATCC 23848 was also determined, to serve as an independent control.

Plasmid DNA isolation. The Wizard Plus SV Minipreps DNA purification kit (Promega) was used for plasmid DNA isolation. 


\section{RESULTS AND DISCUSSION}

\section{Morphological characteristics}

Strain $\mathrm{LV}^{\mathrm{T}}$ formed smooth, round, convex, non-slimy, small $(2-3 \mathrm{~mm}$ in diameter), reddish colonies on solid media. Strain $\mathrm{LV} 3^{\mathrm{T}}$ grew aerobically on most agar media (except nutrient agar) at temperatures of $-2,10$ and $18^{\circ} \mathrm{C}$, but did not grow at $25^{\circ} \mathrm{C}$ or higher. Colourless colonies were occasionally observed. Cells reached a higher density when grown in TSB or LB than when grown in R2 broth. The generation time in TSB was estimated to be 10,20 and $29 \mathrm{~h}$ at 18,10 and $5{ }^{\circ} \mathrm{C}$, respectively. The cells grew more slowly at $21^{\circ} \mathrm{C}$ than they did at $18{ }^{\circ} \mathrm{C}$, indicating that $18^{\circ} \mathrm{C}$ is the optimal temperature for growth (Fig. 1). The upper temperature limit for growth was $22^{\circ} \mathrm{C}$. The cells grew at $-2{ }^{\circ} \mathrm{C}$, even though there was an extended lag phase that was independent of the growth temperature of the inoculum. Members of only three other genera in the family Microbacteriaceae (Subtercola, Cryobacterium and Frigoribacterium) have optimal growth temperatures of $18^{\circ} \mathrm{C}$ or below. Cryobacterium is the only genus with an upper growth temperature limit lower than that of strain $\mathrm{LV}^{\mathrm{T}}$ (Table 1). Formation of reddish intracellular pigment occurred soon after the start of the exponential phase in all cultures. Pigment formation is a common characteristic of representatives of the family Microbacteriaceae (Table 1). The cells also reached a high cell density and remained viable after prolonged incubation in TSB at -2 and $10^{\circ} \mathrm{C}$, with over $10^{10}$ c.f.u. $\mathrm{ml}^{-1}$ remaining after 4 months. The cell density dropped to $10^{9}$ c.f.u. $\mathrm{ml}^{-1}$ after 5 months incubation and there were no viable cells after 7 months.

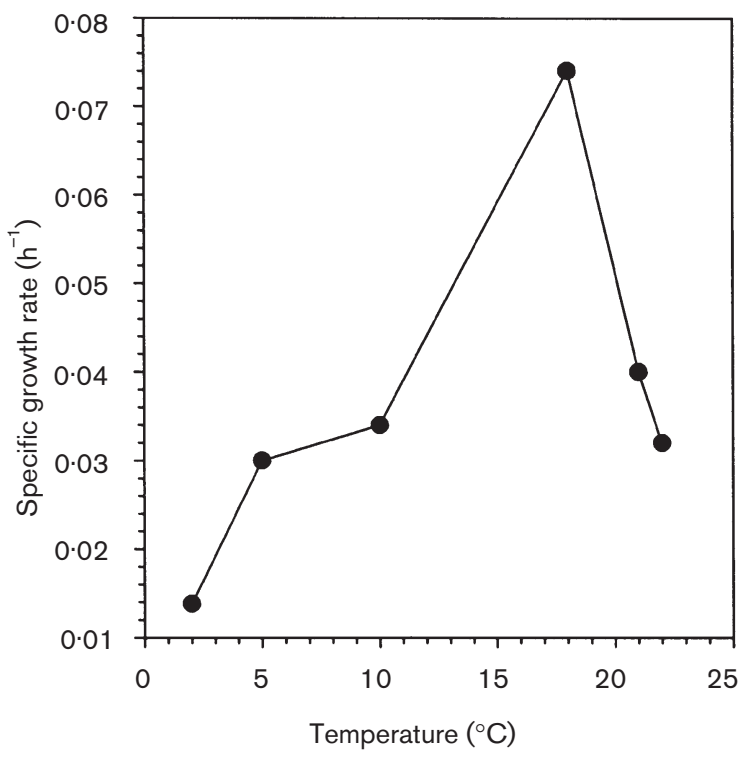

Fig. 1. Influence of temperature on the growth of strain $\mathrm{LV}^{\top}$ in TSB. Specific growth rates were calculated from estimated generation time values at different temperatures and are the means of at least three experiments.
Microscopic observations showed that the cells were motile, Gram-positive, non-spore-forming, pleomorphic, short slender rods, about $0 \cdot 15-0 \cdot 2 \mu \mathrm{m}$ in width and $1 \cdot 0-1 \cdot 2 \mu \mathrm{m}$ in length. Cells from freshly inoculated cultures were longer than those from older cultures; however, no true rod-coccus cycle (as in species of the genera Arthrobacter, Leifsonia and Frigoribacterium) was observed. Clumps of cells were often formed in broth cultures. In addition, the cells frequently appeared swollen at the ends or in the middle. SEM showed extremely slender cells with enlarged, bulbous protuberances that were approximately $0.8 \mu \mathrm{m}$ in diameter (Fig. 2a, b). Some of the cells were slightly curved, but lacked the typical fragmented shapes often seen with members of the genus Arthrobacter. The rods were slender and some appeared to enter the $0 \cdot 2 \mu \mathrm{m}$ filter pores (Fig. 2a). Most protuberances appeared to be in the central part of the cells. To determine whether the protuberances were formed during a certain growth stage or were due to growth at a specific temperature or in a particular medium, additional cultures that had been grown for different times, at various temperatures and in different media were examined. These structures were observed in pigmented and non-pigmented cells of all growth stages and culture conditions.

In order to determine whether these unique protuberances contained specialized material or inclusion bodies, we examined the cells using TEM (Fig. $2 \mathrm{c}$ and d). The micrographs showed uniform cytoplasmic material within the cells, without any disruption of cell-wall integrity or intracellular components in the protuberances. After 150 days incubation, the cells had the same morphology, which showed that the protuberances were not simply cell-wall 'blebs' being formed in preparation for cell lysis. Although the function of the protuberances is unknown, they appeared to be unrelated to any specific growth stage or condition. It may be that these structures provide an enhanced surface area for nutrient transport for the otherwise small cells, or are the result of an altered rodcoccus cycle, commonly observed among other Grampositive, non-spore-forming aerobes.

\section{Physiological characteristics}

Initially, strain $\mathrm{LV}^{\mathrm{T}}$ was chosen for study because it hydrolysed X-Gal, indicating that it might have a coldactive $\beta$-galactosidase. Other enzymic characteristics were tested using API CORYNE test strips. The strain showed positive enzymic activities for pyrazinamidase, pyrrolidonyl arylamidase, alkaline phosphatase (weak), $\beta$-galactosidase (weak), $\alpha$-glucosidase, $\beta$-glucosidase and catalase, and was negative for nitrate reductase, $\beta$-glucuronidase, $N$-acetyl- $\beta$ glucosidase and urease. It did not hydrolyse gelatin and did not form acid from glucose, ribose, xylose, mannitol, maltose, lactose, sucrose or glycogen. In other tests, the strain did not grow anaerobically or in the presence of $2 \cdot 5,5$ or $10 \% \mathrm{NaCl}$ and did not form heat-resistant spores. A small (approx. $900 \mathrm{bp}$ ) plasmid was found in strain $\mathrm{LV}^{\mathrm{T}}$. Further characterization of this plasmid is ongoing. 
Table 1. Distinguishing characteristics of genera in the family Microbacteriaceae

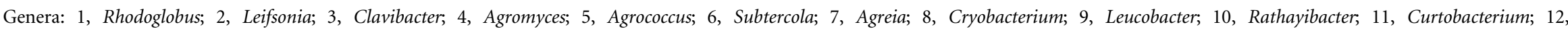

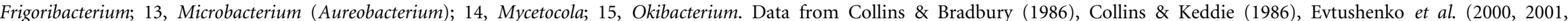

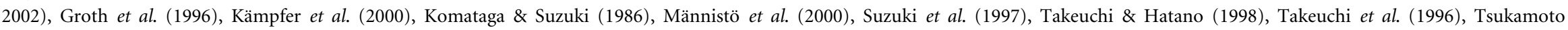
et al. (2001), Zgurskaya et al. (1992, 1993) and this study.

\begin{tabular}{|c|c|c|c|c|c|c|c|c|c|c|c|c|c|c|c|}
\hline Characteristic & 1 & 2 & 3 & 4 & 5 & 6 & 7 & 8 & 9 & 10 & 11 & 12 & 13 & 14 & 15 \\
\hline Colony colour ${ }^{*}$ & $\mathrm{R}$ & $\mathrm{Y}, \mathrm{W}$ & $\mathrm{W}, \mathrm{Y}, \mathrm{O}, \mathrm{P}, \mathrm{BL}$ & $\mathrm{Y}$ & $\mathrm{W}, \mathrm{Y}, \mathrm{O}$ & $\mathrm{Y}$ & $\mathrm{Y}, \mathrm{O}$ & NR & B & NR & $\mathrm{Y}, \mathrm{O}, \mathrm{W}, \mathrm{P}$ & $\mathrm{Y}$ & $\mathrm{W}, \mathrm{O}$ & YW & $\mathrm{Y}$ \\
\hline \multicolumn{16}{|l|}{ Growth temp. $\left({ }^{\circ} \mathrm{C}\right)$ : } \\
\hline Range & $-2-21$ & $7-37$ & Up to 35 & Up to 37 & Up to 37 & $-2-28$ & Up to 37 & $<18$ & Up to 37 & $<37$ & Up to 35 & $0-28$ & $10-40$ & $>4-33$ & $7-37$ \\
\hline Optimum & 18 & $24-28$ & $21-26$ & $26-30$ & 28 & $15-17$ & $24-26$ & $9-12$ & 28 & $24-28$ & $24-27$ & $4-10$ & 30 & 25 & $24-27$ \\
\hline DNA $\mathrm{G}+\mathrm{C}$ content $(\mathrm{mol} \%)$ & 62 & $66-73$ & $67-78$ & $70-72$ & 74 & $64-68$ & 67 & 65 & 66 & $63-72$ & $68-75$ & 72 & $65-75$ & $64-65$ & 67 \\
\hline Diamino acid $\dagger$ & Orn & DAB & DAB & $\mathrm{DAB}$ & $\mathrm{DAB}$ & $\mathrm{DAB}$ & DAB/Orn & DAB & $\mathrm{DAB}$ & DAB & Orn & Lys & Lys/Orn & Lys & Lys \\
\hline \multirow{4}{*}{$\begin{array}{l}\text { Major fatty acids } \\
(\geqslant 5 \%) \ddagger\end{array}$} & $\mathrm{a}-\mathrm{C}_{15: 0}$ & $\mathrm{a}-\mathrm{C}_{15: 0}$ & $\mathrm{a}-\mathrm{C}_{15: 0}$ & $\mathrm{a}, \mathrm{i}$ & $\mathrm{a}-\mathrm{C}_{15: 0}$ & $\mathrm{a}-\mathrm{C}_{15: 0}$ & $\mathrm{a}-\mathrm{C}_{15: 0}$ & $\mathrm{a}-\mathrm{C}_{15: 0}$ & $\mathrm{a}-\mathrm{C}_{15: 0}$ & $a-C_{15: 0}$, & $\mathrm{a}-\mathrm{C}_{15: 0}$ & $\mathrm{a}-\mathrm{C}_{15: 0}$ & $a-C_{15: 0}$ & $a-C_{15: 0}$ & $a-C_{15: 0}$ \\
\hline & $\mathrm{i}-\mathrm{C}_{16: 0}$ & $\mathrm{i}-\mathrm{C}_{16: 0}$ & i- $C_{16: 0}$, & & i- $C_{16: 0}$ & $\mathrm{i}-\mathrm{C}_{16: 0}$ & $\mathrm{i}-\mathrm{C}_{16: 0}$, & $\mathrm{i}-\mathrm{C}_{16: 0}$ & $\mathrm{i}-\mathrm{C}_{16: 0}$ & $\mathrm{i}-\mathrm{C}_{16: 0}$ & $\mathrm{i}-\mathrm{C}_{16: 0}$, & $\mathrm{i}-\mathrm{C}_{16: 0}$ & $\mathrm{i}-\mathrm{C}_{16: 0}$ & $\mathrm{i}-\mathrm{C}_{16: 0}$ & $i-C_{16: 0}$ \\
\hline & $\mathrm{a}-\mathrm{C}_{17: 0}$ & $\mathrm{a}-\mathrm{C}_{17: 0}$ & $a-C_{17: 0}$ & & $\mathrm{a}-\mathrm{C}_{17: 0}$ & $\mathrm{a}-\mathrm{C}_{17: 0}$ & $a-C_{17: 0}$ & $\mathrm{a}-\mathrm{C}_{17: 0}$ & $\mathrm{a}-\mathrm{C}_{17: 0}$ & $a-C_{17: 0}$ & $a-C_{17: 0}$ & $\mathrm{C}_{16: 0}$ & $\mathrm{a}-\mathrm{C}_{17: 0}$ & $a-C_{17: 0}$ & $\mathrm{a}-\mathrm{C}_{17: 0}$, \\
\hline & $\mathrm{a}-\mathrm{C}_{15: 1}$ & & & & $a-C_{15: 1}$ & $\begin{array}{l}a-C_{15: 1}, \\
\text { a- } C_{14: 0}\end{array}$ & & $\begin{array}{l}\text { i- } C_{15: 0} \\
a-C_{15: 1}\end{array}$ & & & $\begin{array}{l}\text { a- } C_{15: 1}, \\
\text { ch }_{17: 0}\end{array}$ & $a-C_{15: 1}$ & $\mathrm{i}-\mathrm{C}_{15: 0}$ & & $\mathrm{i}-\mathrm{C}_{15: 0}$ \\
\hline Major menaquinones & 11,12 & 10,11 & 9 & 12 & 11,12 & 9,10 & 10 & 10 & 11 & 10 & 9 & 9 & $11,12,13$ & 10 & 10,11 \\
\hline
\end{tabular}

${ }^{\star} \mathrm{R}$, Red; W, white; Y, yellow; O, orange; P, pink; BL, blue; B, brown; YW, yellowish-white; NR, not reported.

$\dagger$ Orn, Ornithine; Lys, lysine.

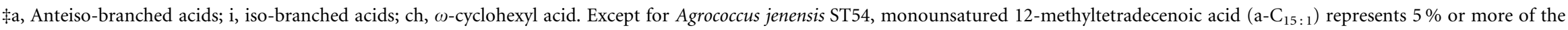
total only when the strains were grown at lower temperatures $\left(\leqslant 10^{\circ} \mathrm{C}\right)$. 

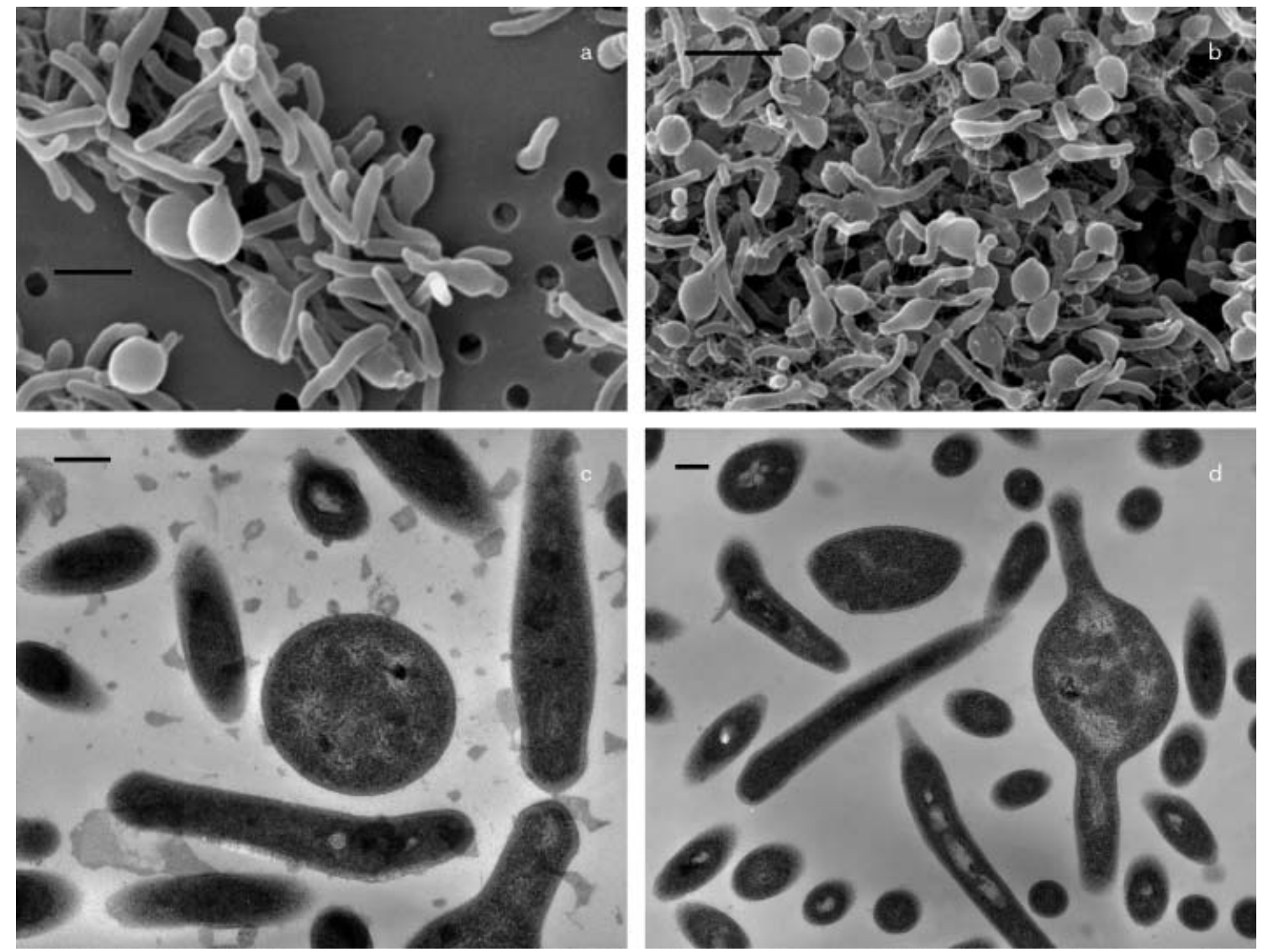

Fig. 2. Morphology of strain $\operatorname{LV}^{\top}$ cells: $(a, b)$ scanning electron micrographs (bars, $\left.1 \mu \mathrm{m}\right)$; (c, d) transmission electron micrographs (bars, $200 \mathrm{~nm}$ ).

\section{$16 S$ rRNA gene sequence and phylogenetic analysis}

The 16S rRNA gene sequence amplified from strain $\mathrm{LV}^{\mathrm{T}}$ DNA was analysed using the maximum-parsimony, maximum-likelihood and distance methods. Distance analysis results using the Jukes-Cantor model with equal rates for variable sites are presented (Fig. 3). These results showed that strain $\mathrm{LV}^{\mathrm{T}}$ is related to, but phylogenetically distinct from, organisms belonging to the genera Agreia, Subtercola and Leifsonia. The grouping of strain $\mathrm{LV}^{\mathrm{T}}$ with the uncharacterized strains 'Leifsonia rubeus', Corynebacterium strain QSSC 3-5 and 'Leifsonia aureus' was supported by high bootstrap values (Fig. 3).

A distance matrix table generated using the Jukes-Cantor model showed that the distances between sequences from strain $\mathrm{LV}^{\mathrm{T}}$ and the closest type strains (Agreia bicolorata VKM Ac- $1804^{\mathrm{T}}$, Subtercola pratensis DSM $14246^{\mathrm{T}}$, Subtercola boreus $\mathrm{K}_{300}{ }^{\mathrm{T}}$, Leifsonia naganoensis $\mathrm{DB} 103^{\mathrm{T}}$, Leifsonia poae VKM Ac- $1401^{\mathrm{T}}$, Leifsonia aquatica DSM $20146^{\mathrm{T}}$, Leifsonia cynodontis MDE ${ }^{\mathrm{T}}$, Leifsonia shinshuensis DB $102^{\mathrm{T}}$ and Subtercola frigoramans $\mathrm{K} 265^{\mathrm{T}}$ ) were $4 \cdot 92,4 \cdot 69$, $5 \cdot 12,5 \cdot 12,5 \cdot 13,5 \cdot 45,5 \cdot 98,6 \cdot 09$ and $6 \cdot 15 \%$, respectively. These values are either above or on the borderline of the accepted values for a genus (Rosselló-Mora \& Amann, 2001). The $16 \mathrm{~S}$ rDNA sequence of strain $\mathrm{LV}^{\mathrm{T}}$ also groups with some less well-characterized strains and is $0.7 \%$ distant from ' $L$. rubeus', $2 \cdot 12 \%$ from Corynebacterium strain QSSC 3-5 and $2 \cdot 79 \%$ from ' $L$. aureus'. Both ' $L$. rubeus' and 'L. aureus' were isolated from a pond in the Wright Valley, Antarctica, which is within 100 miles of the lake from which strain LV3 ${ }^{\mathrm{T}}$ was isolated. Strains QSSC 3-5 and QSSC 9-20 were isolated from an Antarctic quartz stone sublithic community (Smith et al., 2000) and Cryobacterium psychrophilum JCM $1463^{\mathrm{T}}$ was isolated from Antarctic soil (Suzuki et al., 1997). Although S. boreus $\mathrm{K}^{3} 00^{\mathrm{T}}$, S. frigoramans $\mathrm{K}^{265^{\mathrm{T}}}$ (Männistö et al., 2000) and Frigoribacterium faeni $801^{\mathrm{T}}$ (Kämpfer et al., 2000) were not isolated from Antarctic samples, they are psychrophilic. Based on the distances between ' $L$. rubeus' and ' $L$. aureus' and the other members of the genus Leifsonia, as well as the distance between strain QSSC 3-5 and the other members of the genus Corynebacterium, these organisms may need to be included in the newly proposed genus Rhodoglobus.

In addition, during analysis of the $16 \mathrm{~S}$ rRNA gene sequences, we observed that the sequence for strain $\mathrm{LV}^{\mathrm{T}}$ contained a $13 \mathrm{bp}$ insertion that was present in only a few related $16 \mathrm{~S}$ 


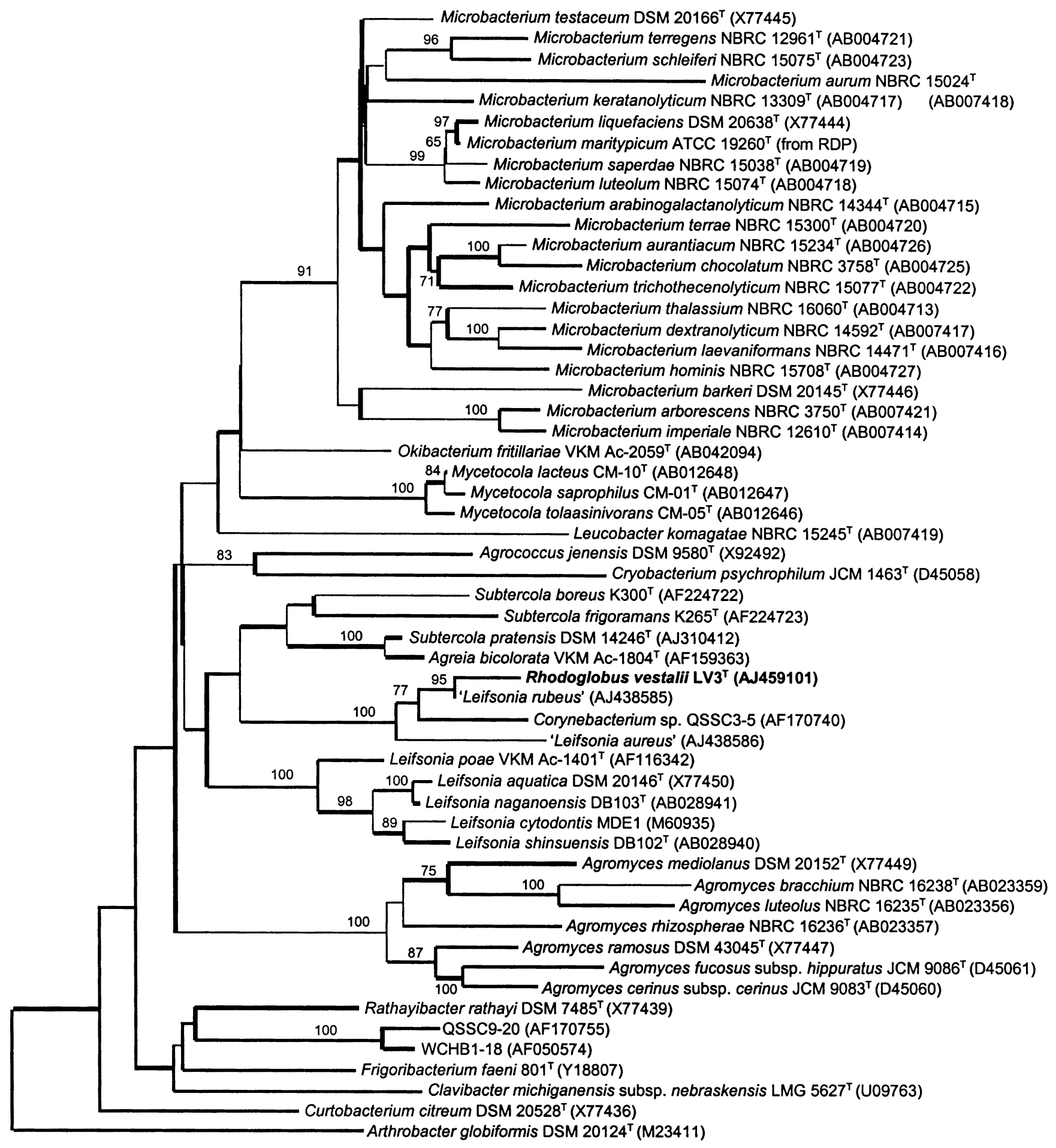

$\overline{0.005}$

Fig. 3. Phylogenetic tree based on distance analysis (neighbour-joining algorithm using the Jukes-Cantor model with equal rates for variable sites) of the $16 \mathrm{~S}$ rRNA gene sequence of isolate LV3 ${ }^{\top}$ compared with 54 closely related sequences. Bar, $0 \cdot 005$ substitutions per site.

rRNA genes. Insertions with an almost-identical sequence were found in 'L. rubeus' and 'L. aureus', and insertions with similar sequences were found in S. frigoramans $\mathrm{K} 265^{\mathrm{T}}$,
C. psychrophilum JCM $1463^{\mathrm{T}}$ and strains QSSC 9-20 and WCHB 1-18 (Dojka et al., 1998). However, insertions were not found in S. boreus $\mathrm{K}^{2} 00^{\mathrm{T}}$, S. pratensis DSM $14246^{\mathrm{T}}$, 


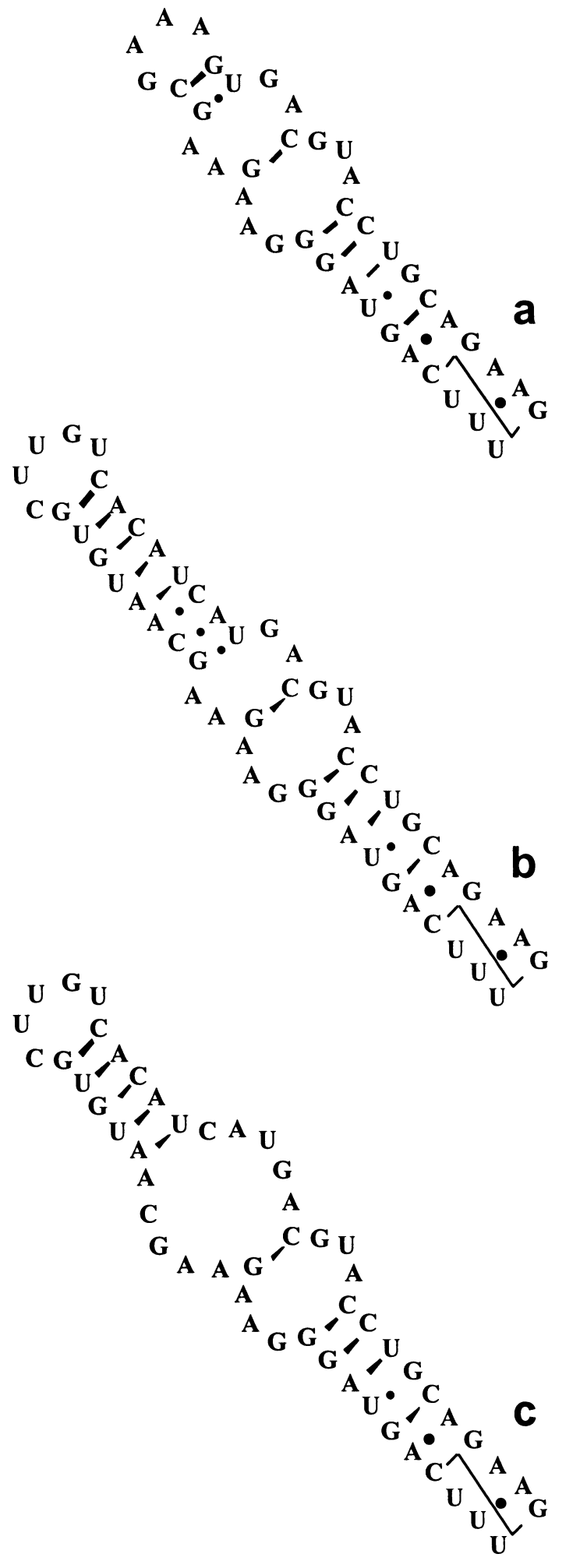

Fig. 4. Diagrams illustrating the inserted nucleotides in the rRNA gene sequence of strain $\mathrm{LV}^{\top}{ }^{\top}$ in comparison with that of A. globiformis. (a) Part of the secondary structure of the $16 \mathrm{~S}$ rRNA gene of $A$. globiformis corresponding to nucleotides 436-476; (b, c) proposed secondary structures of the inserted 16S rRNA gene sequence for strain $\mathrm{LV}^{\top}{ }^{\top}$.
Table 2. Fatty acid composition (\%) of strain $\mathrm{LV}^{\top}$ Strain $\mathrm{LV} 3^{\mathrm{T}}$ was grown in $\mathrm{LB}$ at $-2{ }^{\circ} \mathrm{C}$ and in $\mathrm{TSB}$ at $18^{\circ} \mathrm{C}$.

\begin{tabular}{|lcc|}
\hline Fatty acid & \multicolumn{2}{c|}{ Growth temperature $\left({ }^{\circ} \mathbf{C}\right)$} \\
\cline { 2 - 3 } & $-\mathbf{2}$ & $\mathbf{1 8}$ \\
\hline $\mathrm{i}-\mathrm{C}_{14: 0}$ & $1 \cdot 03$ & $1 \cdot 11$ \\
$\mathrm{i}-\mathrm{C}_{15: 0}$ & $1 \cdot 94$ & $0 \cdot 79$ \\
$\mathrm{a}-\mathrm{C}_{15: 0}$ & $34 \cdot 54$ & $53 \cdot 16$ \\
$\mathrm{i}-\mathrm{C}_{15: 1}$ & $0 \cdot 20$ & $0 \cdot 0$ \\
a- $\mathrm{C}_{15: 1}$ & $23 \cdot 19$ & $2 \cdot 25$ \\
$\mathrm{C}_{16: 0}$ & $0 \cdot 33$ & $0 \cdot 55$ \\
$\mathrm{i}-\mathrm{C}_{16: 0}$ & $23 \cdot 18$ & $18 \cdot 76$ \\
$\mathrm{i}-\mathrm{C}_{17: 0}$ & $0 \cdot 87$ & $0 \cdot 58$ \\
$\mathrm{a}-\mathrm{C}_{17: 0}$ & $14 \cdot 72$ & $22 \cdot 62$ \\
$\mathrm{C}_{17: 1} \omega 5 c$ & $0 \cdot 0$ & $0 \cdot 18$ \\
\hline
\end{tabular}

Agreia bicolorata VKM Ac- $1804^{\mathrm{T}}$ (Evtushenko et al., 2001), strain QSSC 3-5 or any of the type strains in the genus Leifsonia. The presence of insertions did not correspond to the isolates' geographical origin or to their mode of growth (psychrophilic). The insertion sequence of strain $\mathrm{LV}^{\mathrm{T}}$ was mapped (Fig. 4a) onto the secondary structure of the most closely related organism (Arthrobacter globiformis DSM $20124^{\mathrm{T}}$ ) for which a structure has been generated (Gutell, 1994; http://www.rna.icmb.utexas.edu). The partial secondary structure presented in Fig. 4a corresponded to nucleotides 436-476 of the 16S rRNA gene sequence of Arthrobacter globiformis DSM 20124 ${ }^{\mathrm{T}}$. As the inserted nucleotides can form a number of possible hairpin structures that would stabilize the insertion (Fig. 4b), it is unlikely that they were artefacts. The combination of the distance of the $16 \mathrm{~S}$ rRNA gene sequence for strain $\mathrm{LV} 3^{\mathrm{T}}$ from that of other type strains, plus its insertion sequence, supports the designation of strain $\mathrm{LV} 3^{\mathrm{T}}$ as a representative of a novel genus.

\section{Chemotaxonomic characteristics}

The predominant fatty acids in cells of strain $\mathrm{LV} 3^{\mathrm{T}}$ cultured at $18{ }^{\circ} \mathrm{C}$ were branched-chain saturated fatty acids: anteiso$\mathrm{C}_{15: 0}$, iso- $\mathrm{C}_{16: 0}$ and anteiso- $\mathrm{C}_{17: 0}$ (Table 2). Most species closely related to strain $\mathrm{LV}^{\mathrm{T}}$ also contain significant amounts of branched-chain fatty acids (Table 2). When strain $\mathrm{LV} 3{ }^{\mathrm{T}}$ was cultured at $-2{ }^{\circ} \mathrm{C}$, the amount of anteiso$\mathrm{C}_{15: 0}$ decreased by $1 \cdot 5$-fold and the amount of the unsaturated fatty acid anteiso- $\mathrm{C}_{15: 1}$ increased 10-fold. These results are consistent with changes in the ratio of unsaturated and saturated fatty acids found in other Gram-positive non-spore-forming rods grown at different temperatures. For example, Cryobacterium psychrophilum (previously known as 'Curtobacterium psychrophilum'), which does not grow at above $18{ }^{\circ} \mathrm{C}$, exhibits a decrease in anteiso- $\mathrm{C}_{15: 0}$ and anteiso- $\mathrm{C}_{17: 0}$ and a sixfold increase in anteiso- $\mathrm{C}_{15: 1}$ when cultured at $4{ }^{\circ} \mathrm{C}$ (Suzuki et al., 1997). Anteiso- $\mathrm{C}_{15: 1}$ was found in cells of $S$. frigoramans when grown at temperatures $\leqslant 15^{\circ} \mathrm{C}$ (Männistö et al., 2000). 
Adjustment of the fatty acid composition may increase membrane fluidity at lower temperatures. The majority of bacterial species contain straight-chain saturated and unsaturated fatty acids, and maintaining membrane fluidity may be accomplished by increasing the amount of unsaturated and short-chain fatty acids at lower temperatures (Kaneda, 1991).

Analyses showed that the diamino acid in the peptidoglycan is ornithine (Table 1). Significant amounts of alanine, glycine and glutamic acid were also found, and only small amounts of lysine were detected. GC-MS results confirmed that lysine was present only in small quantities and homoserine was present only in trace amounts. Based on the results of the quantitative amino acid analyses, the molar ratio of glutamic acid to glycine to alanine to ornithine was $1: 1 \cdot 5: 1 \cdot 1: 1 \cdot 4$. Strain $\mathrm{LV}^{\mathrm{T}}$ peptidoglycan seems to be closest to type B2 $\alpha$ (Schleifer \& Kandler, 1972), although the relative amounts of the amino acids are not totally consistent with this type.

Species closely related to strain $\mathrm{LV} 3^{\mathrm{T}}$ have cell walls comprised of type-B peptidoglycan, although the diamino acid differs between the genera of the family Microbacteriaceae. The closest characterized phylogenetic relatives of strain $\mathrm{LV} 3^{\mathrm{T}}$, including S. boreus and S. frigoramans (Männistö et al., 2000), contain diaminobutyric acid (DAB) as the diamino acid. Agreia bicolorata (Evtushenko et al., 2001) contains both $\mathrm{DAB}$ and ornithine; another organism that contains this unusual combination is $S$. pratensis (Behrendt et al., 2002), which is currently being reclassified. Many Microbacterium species, including reclassified Aureobacterium species (Takeuchi \& Hatano, 1998) and Curtobacterium species (Komataga \& Suzuki, 1986), contain ornithine. Microbacterium species, Mycetocola saprophilus, Mycetocola tolaasinivorans, Mycetocola lacteus (Tsukamoto et al., 2001) and Okibacterium fritillariae (Evtushenko et al., 2002) contain lysine.

Cells of strain $\mathrm{LV}^{\mathrm{T}}$ contained $65 \% \mathrm{MK}-12,35 \% \mathrm{MK}-11$ and small amounts of MK-10 and MK-13. The presence of saturated menaquinones is characteristic of members of the family Microbacteriaceae, but close relatives of strain $\mathrm{LV}^{\mathrm{T}}$ do not have the same menaquinone composition. For example, MK-10 is the major menaquinone in Agreia bicolorata (Evtushenko et al., 2001) and MK-10 and MK-11 are the major menaquinones in S. pratensis (Behrendt et al., 2002). S. boreus and S. frigoramans (Männistö et al., 2000) have predominantly MK-9 and MK-10. The menaquinone composition of strain $\mathrm{LV}^{\mathrm{T}}$ also distinguishes it from other genera in the family Microbacteriaceae.

\section{DNA G + C content}

The $\mathrm{G}+\mathrm{C}$ content for the genomic DNA of strain $\mathrm{LV}^{\mathrm{T}}$ was calculated to be $62 \mathrm{~mol} \%$, based on its melting temperature. This value is consistent with the $\mathrm{G}+\mathrm{C}$ content for the 900 bp plasmid found in strain $\mathrm{LV}^{\mathrm{T}}$, which was found to be $59 \mathrm{~mol} \%$ (V. I. Miteva \& J. E. Brenchley, unpublished data).
The DNA G $+\mathrm{C}$ content for strain $\mathrm{LV}^{\mathrm{T}}$ may be another distinguishing feature, as it was slightly lower than those reported for related organisms such as $L$. poae at 66-73 mol\% (Evtushenko et al., 2000) and Agreia bicolorata at $67 \mathrm{~mol} \%$ (Evtushenko et al., 2001).

\section{Description of Rhodoglobus gen. nov.}

Rhodoglobus (Rho.do.glo'bus. Gr. n. rhodon the rose; L. masc. n. globus ball; N.L. masc. n. rhodoglobus red ball).

Cells are aerobic, Gram-positive, easily decolourized, motile and non-spore-forming. Colonies are smooth, round, convex, non-slimy, translucent, reddish and small (2-3 $\mathrm{mm}$ in diameter). Individual cells are slender rods (mean cell size of $0 \cdot 15-0 \cdot 2 \times 1-1 \cdot 2 \mu \mathrm{m}$ ), with bulbous protuberances (mean diameter $0.8 \mu \mathrm{m}$ ) seen at all stages of growth. Cells grow aerobically at $-2-21^{\circ} \mathrm{C}$. Cell walls contain ornithine as the diagnostic amino acid. Predominant fatty acids are anteiso- $C_{15: 0}$, anteiso- $C_{17: 0}$ and iso- $C_{16: 0}$. Major menaquinones are MK-11 and MK-12. The type species is Rhodoglobus vestalii.

\section{Description of Rhodoglobus vestalii sp. nov.}

Rhodoglobus vestalii [ves.ta'li.i. N.L. gen. n. vestalii in honour of the late J. Robie Vestal, who studied Antarctic micro-organisms and was a mentor to one of the authors (P.P.S.)].

The following characteristics are shown in addition to those that define the genus. Cells do not exhibit a marked rodcoccus cycle and grow optimally at $18{ }^{\circ} \mathrm{C}$. G $+\mathrm{C}$ content of the DNA is approximately $62 \mathrm{~mol} \%$. Major cellular fatty acids are anteiso- and iso-branched fatty acids. When cells are grown at $-2{ }^{\circ} \mathrm{C}$, the amount of the unsaturated fatty acid anteiso- $\mathrm{C}_{15: 1}$ increases substantially and the amount of anteiso- $\mathrm{C}_{15: 0}$ decreases. Cells show positive enzymic activities for pyrazinamidase, pyrrolidonyl arylamidase, alkaline phosphatase (weak), $\beta$-galactosidase (weak), $\alpha$ glucosidase, $\beta$-glucosidase and catalase, but are negative for nitrate reductase, $\beta$-glucuronidase, $N$-acetyl- $\beta$-glucosidase and urease. Cells do not hydrolyse gelatin and do not form acid from glucose, ribose, xylose, mannitol, maltose, lactose, sucrose or glycogen. The $16 \mathrm{~S}$ rRNA gene sequence contains an insertion of 13 nucleotides that is shared with some of its most closely related neighbours.

The type strain, $\mathrm{LV}^{\mathrm{T}}\left(=\right.$ ATCC BAA- $\left.534^{\mathrm{T}}=\mathrm{CIP} 107482^{\mathrm{T}}\right)$, was isolated from an Antarctic Dry Valley lake.

\section{ACKNOWLEDGEMENTS}

We thank the members of our research group for helpful discussions. This work was supported by Department of Energy grant DE-FG0293ER20117. P.P.S. was also supported by an Alfred P. Sloan Foundation Fellowship in Molecular Evolution from the National Science Foundation and by partial funding from grant NSF/IGERT DGE-9972759 for the Biogeochemical Research Initiative for 
Education (BRIE). P. P. S. and V. I. M. received partial support from the Penn State Astrobiology Center NASA-Ames co-operative agreement NCC2-1057. We thank Rosemary Walsh for preparation of the EM samples and helpful assistance.

\section{REFERENCES}

Behrendt, U., Ulrich, A., Schumann, P., Naumann, D. \& Suzuki, K. (2002). Diversity of grass-associated Microbacteriaceae isolated from the phyllosphere and litter layer after mulching the sward; polyphasic characterization of Subtercola pratensis sp. nov., Curtobacterium herbarum sp. nov. and Plantibacter flavus gen. nov., sp. nov. Int J Syst Evol Microbiol 52, 1441-1454.

Bousfield, I. J., Keddie, R. M., Dando, T. R. \& Shaw, S. (1985). Simple rapid methods of cell wall analysis as an aid in the identification of aerobic cornyneform bacteria. In Chemical Methods in Bacterial Systematics, pp. 221-236. Edited by M. Goodfellow \& D. E. Minnikin. London: Academic Press.

Collins, M. D. \& Bradbury, J. F. (1986). Plant pathogenic species of Corynebacterium. In Bergey's Manual of Systematic Bacteriology, vol. 2, pp. 1276-1283. Edited by P. H. A. Sneath, N. S. Mair, M. E. Sharpe \& J. G. Holt. Baltimore: Wiliams \& Wilkins.

Collins, M. D. \& Keddie, R. M. (1986). Genus Microbacterium OrlaJensen 1919, 179 ${ }^{\mathrm{AL}}$. In Bergey's Manual of Systematic Bacteriology, vol. 2, pp. 1320-1322. Edited by P. H. A. Sneath, N. S. Mair, M. E. Sharpe \& J. G. Holt. Baltimore: Williams \& Wilkins.

Coombs, J. M. \& Brenchley, J. E. (1999). Biochemical and phylogenetic analyses of a cold-active $\beta$-galactosidase from the lactic acid bacterium Carnobacterium piscicola BA. Appl Environ Microbiol 65, 5443-5450.

de Prada, P., Loveland-Curtze, J. \& Brenchley, J. E. (1996). Production of two extracellular alkaline phosphatases by a psychrophilic Arthrobacter strain. Appl Environ Microbiol 62, 3732-3738.

Dojka, M. A., Hugenholtz, P., Haack, S. K. \& Pace, N. R. (1998). Microbial diversity in a hydrocarbon- and chlorinated-solventcontaminated aquifer undergoing intrinsic bioremediation. Appl Environ Microbiol 64, 3869-3877.

Evtushenko, L. I., Dorofeeva, L. V., Subbotin, S. A., Cole, J. R. \& Tiedje, J. M. (2000). Leifsonia poae gen. nov., sp. nov., isolated from nematode galls on Poa annua and reclassification of 'Corynebacterium aquaticum' Leifson 1962 as Leifsonia aquatica (ex Leifson 1962) gen. nov., nom. rev., comb. nov. and Clavibacter xyli Davis et al. 1984 with two subspecies as Leifsonia xyli (Davis et al. 1984) gen. nov., comb. nov. Int J Syst Evol Microbiol 50, 371-380.

Evtushenko, L. I., Dorofeeva, L. V., Dobrovolskaya, T. G., Streshinskaya, G. M., Subbotin, S. A. \& Tiedje, J. M. (2001). Agreia bicolorata gen. nov., sp. nov., to accommodate actinobacteria isolated from narrow reed grass infected by the nematode Heteroanguina graminophila. Int J Syst Evol Microbiol 51, 2073-2079.

Evtushenko, L. I., Dorofeeva, L. V., Krausova, V. I., Gavrish, E. Yu., Yashina, S. G. \& Takeuchi, M. (2002). Okibacterium fritillariae gen. nov., sp. nov., a novel genus of the family Microbacteriaceae. Int J Syst Evol Microbiol 52, 987-993.

Giovannoni, S. J., DeLong, E. F., Schmidt, T. M. \& Pace, N. R. (1990). Tangential flow filtration and preliminary phylogenetic analysis of marine picoplankton. Appl Environ Microbiol 56, 2572-2575.

Groth, I., Schumann, P., Weiss, N., Martin, K. \& Rainey, F. A. (1996). Agrococcus jenensis gen. nov., sp. nov., a new genus of actimomycetes with diaminobutyric acid in the cell wall. Int J Syst Bacteriol 46, 234-239.

Gutell, R. R. (1994). Collection of small subunit (16S- and 16S-like) ribosomal RNA structures: 1994. Nucleic Acids Res 22, 3502-3507.
Gutshall, K. R., Trimbur, D. E., Kasmir, J. J. \& Brenchley, J. E. (1995). Analysis of a novel gene and $\beta$-galactosidase isozyme from a psychrotrophic Arthrobacter isolate. J Bacteriol 177, 1981-1988.

Gutshall, K., Wang, K. \& Brenchley, J. E. (1997). A novel Arthrobacter $\beta$-galactosidase with homology to eucaryotic $\beta$-galactosidases. J Bacteriol 179, 3064-3067.

Kämpfer, P., Rainey, F. A., Andersson, M. A., Nurmiaho-Lassila, E.-L., Ulrych, U., Busse, H.-J., Weiss, N., Mikkola, R. \& SalkinojaSalonen, M. (2000). Frigoribacterium faeni gen. nov., sp. nov., a novel psychrophilic genus of the family Microbacteriaceae. Int J Syst Evol Microbiol 50, 355-363.

Kaneda, T. (1991). Iso- and anteiso-fatty acids in bacteria: biosynthesis, function, and taxonomic significance. Microbiol Rev 55, 288-302.

Komataga, K. \& Suzuki, K.-I. (1986). Genus Curtobacterium Yamada and Komagata $1972425^{\mathrm{AL}}$. In Bergey's Manual of Systematic Bacteriology, vol. 2, pp. 1313-1317. Edited by P. H. A. Sneath, N. S. Mair, M. E. Sharpe and J. G. Holt. Baltimore: Williams and Wilkins.

Loveland, J., Gutshall, K., Kasmir, J., Prema, P. \& Brenchley, J. E. (1994). Characterization of psychrotrophic microorganisms producing $\beta$-galactosidase activities. Appl Environ Microbiol 60, 12-18.

Loveland-Curtze, J., Sheridan, P. P., Gutshall, K. R. \& Brenchley, J. E. (1999). Biochemical and phylogenetic analyses of psychrophilic isolates belonging to the Arthrobacter subgroup and description of Arthrobacter psychrolactophilus, sp. nov. Arch Microbiol 171, 355-363.

Maidak, B. L., Cole, J. R., Lilburn, T. G. \& 9 other authors (2000). The RDP (Ribosomal Database Project) continues. Nucleic Acids Res 28, 173-174.

Mandel, M. \& Marmur, J. (1968). Use of ultraviolet absorbancetemperature profile for determining the guanine plus cytosine content of DNA. Methods Enzymol 12B, 195-206.

Männistö, M. K., Schumann, P., Rainey, F. A., Kämpfer, P., Tsitko, I., Tiirola, M. A. \& Salkinoja-Salonen, M. S. (2000). Subtercola boreus gen. nov., sp. nov. and Subtercola frigoramans sp. nov., two new psychrophilic actinobacteria isolated from boreal groundwater. Int J Syst Evol Microbiol 50, 1731-1739.

Neidhardt, F. C., Ingraham, J. L. \& Schaechter, M. (1990). Physiology of the Bacterial Cell: a Molecular Approach. Sunderland, MA: Sinauer Associates.

Pace, N. R., Stahl, D. A., Lane, D. J. \& Olsen, G. J. (1986). The analysis of natural microbial populations by ribosomal RNA sequences. Adv Microb Ecol 9, 1-55.

Rosselló-Mora, R. \& Amann, R. (2001). The species concept for prokaryotes. FEMS Microbiol Rev 25, 39-67.

Schleifer, K. H. \& Kandler, O. (1972). Peptidoglycan types of bacterial cell walls and their taxonomic implications. Bacteriol Rev 36, 407-477.

Sheridan, P. P. \& Brenchley, J. E. (2000). Characterization of a salttolerant family $42 \beta$-galactosidase from a psychrophilic Antarctic Planococcus isolate. Appl Environ Microbiol 66, 2438-2444.

Smith, M. C., Bowman, J. P., Scott, F. J. \& Line, M. A. (2000). Sublithic bacteria associated with Antarctic quartz stones. Antarct Sci 12, 177-184.

Stackebrandt, E. \& Woese, C. R. (1981). Towards a phylogeny of the actinomycetes and related organisms. Curr Microbiol 5, 197-202.

Suzuki, K., Sasaki, J., Uramoto, M., Nakase, T. \& Komagata, K. (1997). Cryobacterium psychrophilum gen. nov., sp. nov., nom. rev., comb. nov., an obligately psychrophilic actinomycete to accommodate 'Curtobacterium psychrophilum' Inoue and Komagata 1976. Int J Syst Bacteriol 47, 474-478. 
Swofford, D. L. (2002). PAUP (Phylogenetic Analysis Using Parsimony), version 4.0b10. Sunderland, MA: Sinauer Associates.

Takeuchi, M. \& Hatano, K. (1998). Union of the genera Microbacterium Orla-Jensen and Aureobacterium Collins et al. in a redefined genus Microbacterium. Int J Syst Bacteriol 48, 739-747.

Takeuchi, M., Weiss, N., Schumann, P. \& Yokota, A. (1996). Leucobacter komagatae gen. nov., sp. nov., a new aerobic grampositive, nonsporulating rod with 2,4-diaminobutyric acid in the cell wall. Int J Syst Bacteriol 46, 967-971.

Tsukamoto, T., Takeuchi, M., Shida, O., Murata, H. \& Shirata, A. (2001). Proposal of Mycetocola gen. nov. in the family Microbacteriaceae and three new species, Mycetocola saprophilus sp. nov., Mycetocola tolaasinivorans sp. nov. and Mycetocola lacteus sp. nov., isolated from cultivated mushroom, Pleurotus ostreatus. Int J Syst Evol Microbiol 51, 937-944.
Weisburg, W. G., Barns, S. M., Pelletier, D. A. \& Lane, D. J. (1991). $16 \mathrm{~S}$ ribosomal DNA amplification for phylogenetic study. J Bacteriol 173, 697-703.

Zgurskaya, H. I., Evtushenko, L. I., Akimov, V. N., Voyevoda, H. V., Dobrovolskaya, T. G., Lysak, L. V. \& Kalakoutskii, L. V. (1992). Emended description of the genus Agromyces and description of Agromyces cerinus subsp. cerinus sp. nov., subsp. nov., Agromyces cerinus subsp. nitratus sp. nov., subsp. nov., Agromyces fucosus subsp. fucosus sp. nov., subsp. nov., and Agromyces fucosus subsp. hippuratus sp. nov., subsp. nov. Int J Syst Bacteriol 42, 635-641.

Zgurskaya, H. I., Evtushenko, L. I., Akimov, V. N. \& Kalakoutskii, L. V. (1993). Rathayibacter gen. nov., including the species Rathayibacter rathayi comb. nov., Rathayibacter tritici comb. nov., Rathayibacter iranicus comb. nov., and six strains from annual grasses. Int J Syst Bacteriol 43, 143-149. 